\title{
No mutations found in exons of TP53, H-RAS and K-RAS genes in liver of male Wistar rats submitted to a medium-term chemical carcinogenesis assay
}

\author{
Ausência de mutações em éxons dos genes TP53, H-RAS e K-RAS em figado de ratos wistar submetidos a ensaio de \\ carcinogênese química de média duração
}

\begin{tabular}{|c|c|}
\hline $\operatorname{rds}$ & $\begin{array}{r}\text { Erick da } \\
\text { Andréia Ha } \\
\text { Deilson Elgu } \\
\text { Noeme } \\
\text { Daisy Maria Fáve } \\
\text { João Lauro Viana }\end{array}$ \\
\hline $\begin{array}{l}\text { PCR-SSCP } \\
\text { TP53 } \\
\text { RAS } \\
\text { DMBDD } \\
\text { Liver } \\
\text { Chemical carcinogenesis }\end{array}$ & $\begin{array}{l}\text { The standard protocol to evaluate the carcinogenic potential of chemicals is the long-term } \\
\text { bioassay in rodents, not performed in developing countries due to its high cost and complex } \\
\text { operational procedures. Our laboratory has established an alternative medium-term bioassay in } \\
\text { Wistar rats, also called DMBDD assay, based on the paradigm initiation/promotion of chemical } \\
\text { carcinogenesis. This method was accepted by the Brazilian Environment Agency (IBAMA) as an } \\
\text { official source of evidence of carcinogenicity. The aim of this study was to evaluate alterations in } \\
\text { exons } 5 \text { to } 8 \text { of the tumor suppressor gene TP5 } 3 \text { and exons } 1 \text { and } 2 \text { of oncogenes K-RAS and } H \text { - } \\
\text { RAS in neoplastic and preneoplastic hepatic lesions observed in DMBDD assay. The } \\
\text { characterization of these alterations may contribute to the recognition of patterns of damage in } \\
\text { critical genes, as well as to suggest mechanisms of action of the compounds tested in the } \\
\text { protocol. Sixty male Wistar rats were separated into } 3 \text { groups: the first was treated with no } \\
\text { chemicals; the second received five initiating agents and the third received initiation followed } \\
\text { by phenobarbital. Liver DNA samples (obtained from formalin-fixed and paraffin-embedded } \\
\text { tissues after histological analysis) were evaluated by the non-isotopic PCR-SSCP technique. No } \\
\text { changes in any analyzed exons were detected by the PCR-SSCP banding pattern in all } \\
\text { experimental groups. This result suggests that liver mutations in exons } 5 \text { to } 8 \text { of TP53 and } \\
\text { exons } 1 \text { and } 2 \text { of H-RAS and K-RAS are not among the early molecular alterations occurring in } \\
\text { the hepatic carcinogenesis process induced by the DMBDD protocol in male Wistar rats. }\end{array}$ \\
\hline
\end{tabular}

Erick da Cruz Castelli

Andréia Hanada Otake

ui de Oliveira

João Lauro Viana de Camargo

resumo

O teste padrão para identificar o potencial cancerígeno de compostos químicos é o estudo de longa duração em roedores, não realizado no Brasil. Nosso laboratório estabeleceu um teste alternativo de média duração (ensaio DMBDD), baseado no paradigma iniciação-promoção da carcinogênese química, adotado pelo Instituto Brasileiro do Meio Ambiente e dos Recursos Naturais Renováveis (Ibama) como fonte oficial de evidências de carcinogenicidade. Nosso objetivo foi avaliar alterações nos éxons 5 a 8 do gene supressor tumoral TP53 e éxons 1 e 2 dos oncogenes H-RAS e K-RAS em lesões hepáticas neoplásicas e pré-neoplásicas observadas no ensaio DMBDD. A identificação dessas eventuais alterações moleculares permitirá o reconhecimento de um possível padrão de alteração em genes críticos, bem como poderão sugerir mecanismos de ação das substâncias testadas no protocolo

$D M B D D$. Sessenta ratos wistar machos foram separados em três grupos: o grupo I não foi tratado quimicamente; o grupo II recebeu os cinco agentes iniciadores da carcinogênese (DMBDD); o grupo III recebeu a iniciação DMBDD seguida de promoção por Fenobarbital. Amostras de DNA (obtidas após avaliação histopatológica de fígado fixado em formalina e incluído em parafina) foram submetidas à técnica da PCR-SSCP (single strand conformation polymorphism). Não foram detectadas mudanças no padrão de bandeamento da SSCP nos diferentes grupos experimentais em nenhum dos éxons estudados. Os resultados sugerem que, em fígado de ratos Wistar machos, mutações nos éxons 5 a 8 do gene TP53 e éxons 1 e 2 dos genes H-RAS e K-RAS não se incluem dentre as alterações moleculares precoces do processo de carcinogênese hepática induzido pelo protocolo DMBDD. unitermos

PCR-SSCP

TP53

RAS

DMBDD

Figado

Carcinogênese química
1. Bacharel em Ciências Biológicas Modalidade Médica; doutorando do curso de pós-graduação em Patologia da FMB, Unesp, SP, Brasil. 2. Bacharel em Ciências Biológicas Modalidade Médica.

3. Professora doutora, Departamento de Clínica Médica e Patologia, FMVZ, Unesp, SP, Brasil,

4. Pesquisadora III, Departamento de Patologia, FMB, Unesp, SP, Brasil. 5. Professor titular, Departamento de Patologia, FMB, Unesp, SP, Brasil. Trabalho selecionado para concorrer ao Prêmio de Mencão Honrosa e para apresentação oral no Congresso Brasileiro de Patologia, Salvador (BA), Brasil, 2001.

Apoio financeiro: Fapesp - Brasil Grant 00/01525-0. 


\section{Introduction}

Cancer is one of the leading causes of death around the world and industrialized chemicals (e.g., pesticides, food additives, pharmaceutics drugs, industrial solvents and by-products, etc.) are among its known risk factors (13). Governmental agencies are in charge of regulating the production, distribution, use and elimination of those chemicals, for the benefit of the exposed population and the environment. Chemicals that have carcinogenic potential naturally have to be banned or become under strict regulations for marketing and use.

Currently, the standard protocol to evaluate the carcinogenic potential of chemicals is the long-term bioassay in rodents, not performed in developing countries due to its high cost, long experimental period (about 3-4 years) and complex operational procedures (8). Consequently, these countries have been dependent on the know-how generated abroad about the chemical carcinogenesis process. Indeed, they have not been able to establish sound processes for the evaluation of the carcinogenic hazards and risks imposed by putative carcinogens. These circumstances point to the necessity of alternative, more convenient and faster procedures for detection of carcinogenic compounds (15).

Our laboratory has established an alternative mediumterm bioassay based on the initiation/promotion paradigm of chemical carcinogenesis. It was adopted in 1996 by the Brazilian Agency for the Environment (Ibama) as an official source of evidence of chemical carcinogenicity. The Brazilian protocol uses both sexes of the non-isogenic Wistar strain of rats. The initiation step of the carcinogenic process is accomplished by the treatment of the animals with five genotoxic chemicals; afterwards, the animals are treated with at least 3 doses of the test compound. Phenobarbital, a promoter of rodent liver carcinogenesis, is used as a positive control of promotion. Therefore, the assay protocol has three control groups (plain control, control of the initiation step and control of the promotion step) plus the test compound groups (three dose levels). This assay is also called "medium-term bioassay for multiple organs" or DMBDD assay, after the initials of the five initiating agents (8).

In the latter years our laboratory has been working on the better understanding of the mechanisms underlying the process of carcinogenesis in the DMBDD assay. As it is well known, chemical carcinogenesis is a multistep process in which there is progressive accumulation of DNA damage
(20). At least two types of genes play an important role in neoplasia development: protooncogenes and tumor suppressor genes. These genes act in normal cells controlling proliferation, differentiation and cell death processes (32). Among them, TP53 and RAS have been widely studied; damage of these genes are critical in the development of neoplasia and can be identified in different stages of the process (27). There is no enough information about mutations occurring in preneoplastic lesions and in neoplasia found in the DMBDD assay. The characterization of alterations of these genes may contribute to the recognition of damage patterns in critical genes as well as to suggest mechanisms of action of carcinogenic compounds tested in the DMBDD assay.

In the present study we investigated eventual alterations in exons 5, 6,7 and 8 of TP53 tumor suppressor gene and exons 1 and 2 of K-RAS and H-RAS oncogenes by the PCR-SSCP technique, in neoplastic and preneoplastic hepatic lesions observed in males Wistar rats submitted to the three control procedures of the DMBDD assay. These selected gene regions (whose role in the carcinogenic process has been demonstrated) are highly preserved in the filogenetic chain and are considered hotspots for mutations that can induce malignant transformation and promote tumoral progression.

The PCR-SSCP technique (Single Strand Conformation Polymorphism) consists in amplification of specific DNA sequences by the PCR technique (Polimerase Chain Reaction), followed by heat denaturation in the presence of a denaturating buffer, and polyacrilamide gel eletroforesis (PAGE) (18). The presence of at least one altered base in the amplified fragment may induce structural changes of the single strand DNA obtained by denaturation, detectable by differential mobility into the polyacrylamide gel. Either mutated and wild-type sequences are amplified by PCR; then, distinct patterns of electrophoretic migration of both sequences may be observed (33). Reports using this technique have contributed to the better understanding of the genetic alterations in chemically-induced neoplasia $(16,31)$.

\section{Material and methods}

\section{Experimental design}

Sixty male Wistar rats were kept under controlled conditions of light (12 hours light/dark), temperature $\left(22^{\circ} \mathrm{C} \pm 2^{\circ} \mathrm{C}\right)$ and humidity $(55 \pm 10 \%)$. Food and water 
were provided ad libidum. The animals were separated into three experimental groups of 20 rats each, which are the three control groups of the DMBDD assay (Figure 1). Group I (plain control) was not treated with chem2icals during the experiment and Groups II (control of initiation) and III (positive control of promotion) were submitted to subcarcinogenic doses of five initiating agents (Table 1). Two weeks after initiation Group II received plain food and water, while Group III received $0.05 \%$ Phenobarbital mixed in the diet. At the $30^{\text {th }}$ week, the animals were submitted to euthanasia and necropsied. Liver samples were formalin fixed, paraffin-embedded, and processed as usual for histological analisys.

\section{DNA extraction and sample preparation}

Three slices of about $20 \mu \mathrm{m}$ were obtained from each paraffin block, using a microtome under asseptic conditions, which use is restricted to samples that are submitted to PCR. These slices were placed in microcentrifuge tubes and submitted to deparaffinization with xylene. Dehydration was done in sucessive ethanol gradients and dried at $55^{\circ} \mathrm{C}$ for 15 minutes. Tissue digestion was done in digestion buffer (TRIS-Cl $50 \mathrm{mM} \mathrm{pH}$ 8.5 / EDTA $1 \mathrm{mM} \mathrm{pH} 8.0$ / Tween $200.5 \%$ ) with proteinase $\mathrm{K}$ at $400 \mathrm{ng} / \mu \mathrm{L}$. Samples were incubated at $55^{\circ} \mathrm{C}$ until total digestion. This was followed by inativation at $96^{\circ} \mathrm{C}$ for 15 minutes. DNA purification was achieved with CTAB/

\section{Table 1 Initiating agents in the DMBDD assay}

\begin{tabular}{|c|c|c|}
\hline Initiating agent & Route & Organ target \\
\hline DEN (diethylnitrosamine) & i.p. & Liver, esophagus, stomach and ovary \\
\hline MNU (N-methyl-N-nitrosourea) & i.p. & $\begin{array}{l}\text { Esophagus, stomach, intestine, kidney, breast, } \\
\text { urinary bladder, CNS, thyroid and } \\
\text { hematopoietic system }\end{array}$ \\
\hline BBN (butyl-N-4-hydroxybutyl-nitrosamine) & Drinking water & Urinary bladder \\
\hline DMH (dimethyl-hydrazine) & Subcutaneous & Colon \\
\hline DHPN (dihydro-propyl-nitrosamine) & Drinking water & Lung, thyroid and urinary bladder \\
\hline
\end{tabular}

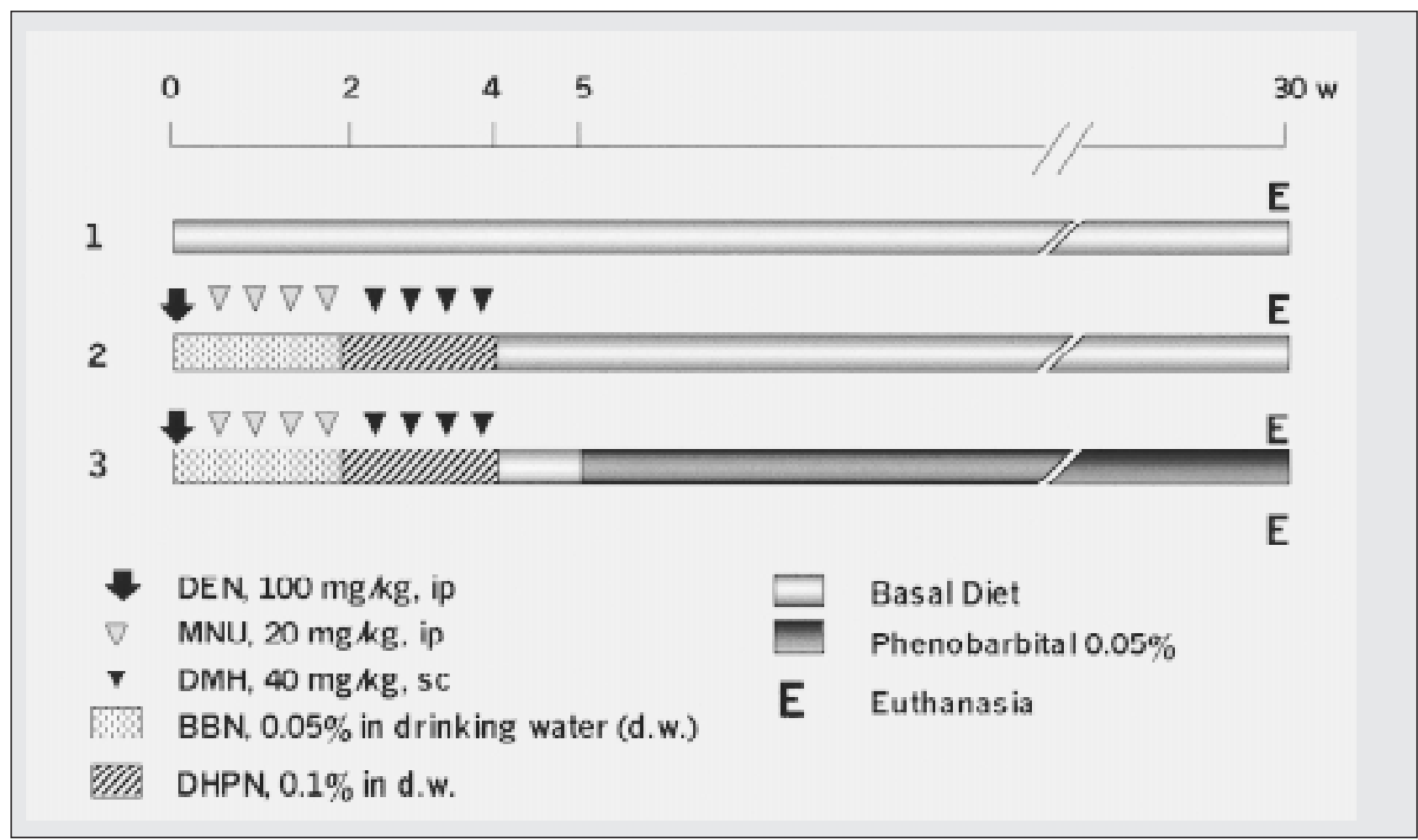

Figure 1 - Control groups of the medium-term bioassay for multiple organs, known as DMBDD assay 
$\mathrm{NaCl}$ solution $(\mathrm{NaCl} 0.87 \mathrm{M}, \mathrm{CTAB} 0.34 \mathrm{M})$ and ethanol precipitation; drying DNA was resuspended in TE solution pH 8.0 (TRIS-Cl 10mM pH 7.5 / EDTA 1mM). DNA quantification was performed with espectrophotometry; the quality (fragmentation level) was accessed by eletroforesis in $2 \%$ agarose gel stained with ethidium bromide.

\section{Polymerase chain reaction (PCR)}

PCR reactions were performed in a GeneAmp System 2400 Thermocycler (Applied Biosystems, Inc.) in a final volume of $25 \mu$ l of dNTPs, PCR-buffer, magnesium chloride, DNA polymerase (Table 2) and the specific primers listed in Table 3.

\section{PCR-SSCP}

For SSCP analysis aliquots of the PCR products $(6 \mu \mathrm{l})$ were mixed with $6 \mu \mathrm{l}$ of denaturing buffer (EDTA $10 \mu \mathrm{M}$ pH 8.0 / Bromophenol Blue 0.025\% / Xylene Cyanole $0.025 \%$ / Formamide $98 \%$ ) for a total volume of $12 \mu \mathrm{l}$. The mixture was heated at $95^{\circ} \mathrm{C}$ for 10 minutes, and immediately kept at $4^{\circ} \mathrm{C}$. The total volume was applied in a $7 \%$ or $14 \%$ polyacrylamide gel, according to the assay protocol. The eletrophoresis was performed in TBE buffer (TRIS $100 \mathrm{mM}$, Boric Acid 9mM, EDTA $1 \mathrm{mM}$ ) during 51/2 hours ( $7 \%$ polyacrylamide) or 12 hours ( $14 \%$ acrylamide) in $100 \mathrm{~V}$ and temperature controled of $6^{\circ} \mathrm{C}$. After electrophoresis, polyacrylamide gel was stained as the following: 5 minutes treatment in a fixate solution (Ethanol $10 \%$ and Acetic Acid $0.75 \%), 10$ minutes in a silver nitrate solution $0.2 \%$, at least 15 minutes in a developing solution $(\mathrm{NaOH} 9 \%$, Formaldeid $0.3 \%$ ) and 10 minutes in the fixate solution.

\section{Results}

Table 4 presents the histologycal liver lesions found after the 30-week experiment. The efficiency of the promotion treatment by $0.05 \%$ Phenobarbital is demonstrated by the increased frequency of benign neoplasia (adenomas) in Group III when compared to Group II.

No changes were detected by the PCR-SSCP analysis in any analyzed exons in all experimental groups. Figures 2 and 3 show PCR-SSCP banding patterns without relevant alterations.

\section{Discussion}

Alterations in the TP53 tumor suppressor gene are frequently found in human neoplasia, mainly in colon, prostate and liver tumors $(28,29)$. TP53 encodes a 53KDa nuclear phosphoprotein ( $\mathrm{p53}$ ) that acts like homodimers formed by four identical polypeptide chains, acting

\section{Table 2 PCR protocol to amplify the target sequences}

\begin{tabular}{|c|c|c|}
\hline Gene & PCR reaction & Cycles \\
\hline TP53 Exon 5 & $\begin{array}{l}\text { Buffer } 1 \mathrm{X}, 2.2 \mathrm{mM} \mathrm{MgCl}, 0,4 \mathrm{mM} \mathrm{dNTP}, 1.5 \\
\mathrm{U} \text { Taq, } 0.2 \mu \mathrm{M} \text { each primer }\end{array}$ & $\begin{array}{l}98^{\circ} \mathrm{C}-10^{\prime}(1 \mathrm{x}) ; 95^{\circ} \mathrm{C}-1^{\prime}, 58^{\circ} \mathrm{C}- \\
1^{\prime}, 72^{\circ} \mathrm{C}-1^{\prime}(35 \mathrm{x}) ; 72^{\circ} \mathrm{C}-7^{\prime}(1 \mathrm{x})\end{array}$ \\
\hline TP53 Exon 6 & $\begin{array}{l}\text { Buffer } 0.8 \mathrm{X}, 2.0 \mathrm{mM} \mathrm{MgCl} 2,0.2 \mathrm{mM} \mathrm{dNTP}, 1.0 \\
\mathrm{U} \text { Taq, } 0,16 \mu \mathrm{M} \text { each primer }\end{array}$ & $\begin{array}{l}98^{\circ} \mathrm{C}-5^{\prime}(1 \mathrm{x}) ; 95^{\circ} \mathrm{C}-1^{\prime}, 57^{\circ} \mathrm{C}- \\
1^{\prime}, 72^{\circ} \mathrm{C}-1^{\prime}(38 \mathrm{x}) ; 72^{\circ} \mathrm{C}-7^{\prime}(1 \mathrm{x})\end{array}$ \\
\hline TP53 Exon 7 & $\begin{array}{l}\text { Buffer } 1 \mathrm{X}, 3.0 \mathrm{mM} \mathrm{MgCl}_{2}, 0.2 \mathrm{mM} \mathrm{dNTP}, 1.0 \\
\mathrm{U} \text { Taq, } 0.2 \mu \mathrm{M} \text { each primer }\end{array}$ & $\begin{array}{l}98^{\circ} \mathrm{C}-5^{\prime}(1 \mathrm{x}) ; 95^{\circ} \mathrm{C}-1^{\prime}, 55^{\circ} \mathrm{C}- \\
1^{\prime}, 72^{\circ} \mathrm{C}-1^{\prime}(35 \mathrm{x}) ; 72^{\circ} \mathrm{C}-7^{\prime}(1 \mathrm{x})\end{array}$ \\
\hline TP53 Exon 8 & $\begin{array}{l}\text { Buffer } 1 \mathrm{X}, 3.0 \mathrm{mM} \mathrm{MgCl}, 0.2 \mathrm{mM} \text { dNTP, } 1.0 \\
\mathrm{U} \text { Taq, } 0.2 \mu \mathrm{M} \text { each primer }\end{array}$ & $\begin{array}{l}98^{\circ} \mathrm{C}-5^{\prime}(1 \mathrm{x}) ; 95^{\circ} \mathrm{C}-1^{\prime}, 55^{\circ} \mathrm{C}- \\
1^{\prime}, 72^{\circ} \mathrm{C}-1^{\prime}(35 \mathrm{x}) ; 72^{\circ} \mathrm{C}-7^{\prime}(1 \mathrm{x})\end{array}$ \\
\hline H-RAS Exon 1 & $\begin{array}{l}\text { Buffer } 1 \mathrm{X}, 2.0 \mathrm{mM} \mathrm{MgCl}, 0.2 \mathrm{mM} \text { dNTP, } 1 \\
\text { U Taq, } 0.15 \mu \mathrm{M} \text { each primer }\end{array}$ & $\begin{array}{l}94^{\circ} \mathrm{C}-5^{\prime}(1 \mathrm{x}) ; 94^{\circ} \mathrm{C}-1^{\prime}, 57^{\circ} \mathrm{C}- \\
30^{\prime \prime}, 72^{\circ} \mathrm{C}-1^{\prime}(35 \mathrm{x}) ; 72^{\circ} \mathrm{C}-7^{\prime}(1 \mathrm{x})\end{array}$ \\
\hline H-RAS Exon 2 & $\begin{array}{l}\text { Buffer } 1 \mathrm{X}, 1.5 \mathrm{mM} \mathrm{MgCl}, 0.2 \mathrm{mM} \text { dNTP, } 1.5 \\
\mathrm{U} \text { Taq, } 0.4 \mu \mathrm{M} \text { each primer }\end{array}$ & $\begin{array}{l}94^{\circ} \mathrm{C}-5^{\prime}(1 \mathrm{x}) ; 94^{\circ} \mathrm{C}-40^{\prime \prime}, 65^{\circ} \mathrm{C}- \\
30^{\prime \prime}, 72^{\circ} \mathrm{C}-1^{\prime}(37 \mathrm{x}) ; 72^{\circ} \mathrm{C}-7^{\prime}(1 \mathrm{x})\end{array}$ \\
\hline K-RAS Exon 1 & $\begin{array}{l}\text { Buffer } 1 \mathrm{X}, 2.0 \mathrm{mM} \mathrm{MgCl}, 0.2 \mathrm{mM} \text { dNTP, } 1.5 \\
\mathrm{U} \text { Taq, } 0.15 \mu \mathrm{M} \text { each primer }\end{array}$ & $\begin{array}{l}94^{\circ} \mathrm{C}-5^{\prime}(1 \mathrm{x}) ; 94^{\circ} \mathrm{C}-45^{\prime \prime}, 55^{\circ} \mathrm{C}- \\
15^{\prime \prime}, 72^{\circ} \mathrm{C}-45^{\prime \prime}(30 \mathrm{x}) ; 72^{\circ} \mathrm{C}-7^{\prime}(1 \mathrm{x})\end{array}$ \\
\hline K-RAS Exon 2 & $\begin{array}{l}\text { Buffer } 1 \mathrm{X}, 1.5 \mathrm{mM} \mathrm{MgCl}, 0.2 \mathrm{mM} \text { dNTP, } 1.0 \\
\mathrm{U} \text { Taq, } 0.2 \mu \mathrm{M} \text { each primer }\end{array}$ & $\begin{array}{l}94^{\circ} \mathrm{C}-5^{\prime}(1 \mathrm{x}) ; 94^{\circ} \mathrm{C}-30^{\prime \prime}, 61^{\circ} \mathrm{C}- \\
30^{\prime \prime}, 72^{\circ} \mathrm{C}-45^{\prime \prime}(35 \mathrm{x}) ; 72^{\circ} \mathrm{C}-7^{\prime}(1 \mathrm{x})\end{array}$ \\
\hline
\end{tabular}


Primers to amplify exons 5, 6, 7 and 8 of TP53 gene and exons 1 and 2 of H-RAS Table 3 and K-RAS genes

\begin{tabular}{|c|c|c|}
\hline Target & Primers $\left(5^{\prime}-3^{\prime}\right)$ & Ampl. \\
\hline TP53 Exon 5 & $\begin{array}{l}\text { P53.5S - GCTGACCTTTGATTCTTTCTC } \\
\text { P53.5A - ACCCTGGACAACCAGTTCTAA }\end{array}$ & $262 \mathrm{pb}$ \\
\hline TP53 Exon 6 & $\begin{array}{l}\text { P53.6S - GCCTCTGACTTATTCTTGC } \\
\text { P53.6A - CAACTTGGCACACAGCTTCC }\end{array}$ & $271 \mathrm{pb}$ \\
\hline TP53 Exon 7 & $\begin{array}{l}\text { P53.7S - TGTGCTGTGCCTCCTCTTGTC } \\
\text { P53.7A - GCGCCTCCACCTTCTTTGTCC }\end{array}$ & $198 \mathrm{pb}$ \\
\hline TP53 Exon 8 & $\begin{array}{l}\text { P53.8S - СССTTGСTCTCTCCTTCCATA } \\
\text { P53.8A - TTGGTACCTTAAGGGTGAAATA }\end{array}$ & $102 \mathrm{pb}$ \\
\hline H-RAS Exon 1 & $\begin{array}{l}\text { H1S - GGTTTGGCAACCCCTGTAGAA } \\
\text { H1A - CCCACCTCTGGCAGGTAGTC }\end{array}$ & $141 \mathrm{pb}$ \\
\hline H-RAS Exon 2 & $\begin{array}{l}\text { H2S - GGACCCTTAAGCTGTGTTCTTTT } \\
\text { H2A - GGGCTAGCCATAGGTGGTCA }\end{array}$ & $227 \mathrm{pb}$ \\
\hline K-RAS Exon 1 & $\begin{array}{l}\text { K1S - GCCTGCTGAAAATGACTGAGTATA } \\
\text { K1A - CTCTATCGTAGGATCATATTCATC }\end{array}$ & $121 \mathrm{pb}$ \\
\hline K-RAS Exon 2 & $\begin{array}{l}\text { K2S - GACTCCTACAGGAAACAAGT } \\
\text { K2a - AGAAAGCCCTCCCCAGTTCT }\end{array}$ & $125 \mathrm{pb}$ \\
\hline
\end{tabular}

Ampl. $=$ amplicon.

Table 4 Hepatic lesions frequencies (\%) found after the 30-week experiment

\begin{tabular}{lccc}
\hline Hepatic lesions & Control (I) & Initiated (II) & Initiated + PB (III) \\
& $n=20$ & $n=19$ & $n=18$ \\
Clear cell foci & - & 31.5 & 22.2 \\
Eosinophylic foci & 5 & 89.5 & 94.5 \\
Basophylic foci & 10 & 84.2 & 66.6 \\
Amphophilic foci & - & 5.2 & 55.5 \\
Adenoma & - & 10.5 & 44.4 \\
Adenocarcinoma & - & - & - \\
Cholangioma & - & - & 5.5 \\
Cholangiocarcinoma & - & 5.2 & - \\
\hline
\end{tabular}

$\mathrm{PB}=0.05 \%$ Phenobarbital.

predominantly as a transcription factor, promoting cell cycle arrest late in the G1 phase or in the G2-S transition (21). This cellular cycle arrest allows DNA repair before division. Among the genes regulated by TP53 are p21 WAF 1 / Cip1 / Sdi1, GADD45, MDM-2, BAX and IGF-BP3 (24). Although as a general rule tumor suppressor genes lose their function when both alleles are disrupted, alteration in a single allele of the TP53 gene is enough for functional deficiency of its products, because interaction between mutated and wild-type chains of the TP53 product builds tetrameric protein hybrids, enable to bind appropriately to DNA, what damages the transcriptional function played by the $\mathrm{p} 53$ protein (7).
RAS oncogenes were first discovered in a murine retrovirus associated to Harvey $(\mathrm{H})$ and Kerstein $(\mathrm{K})$ sarcomas. A third gene was detected in human neuroblastomas (N-RAS) (10). They encode homologous proteins with $21 \mathrm{KDa}$, namely $\mathrm{p} 21^{\mathrm{RAS}}$, which play a role as regulators of intracellular function related to signal transduction (30). P $21^{\text {RAS }}$ is associated with the inner surface of the cell membrane and has homology with members of the $G$ protein family. It has intrinsic GTPasic activity (3), that is lost when the RAS becomes mutated, promoting continuous propagation of proliferating signals and continuous cellular division (30). 


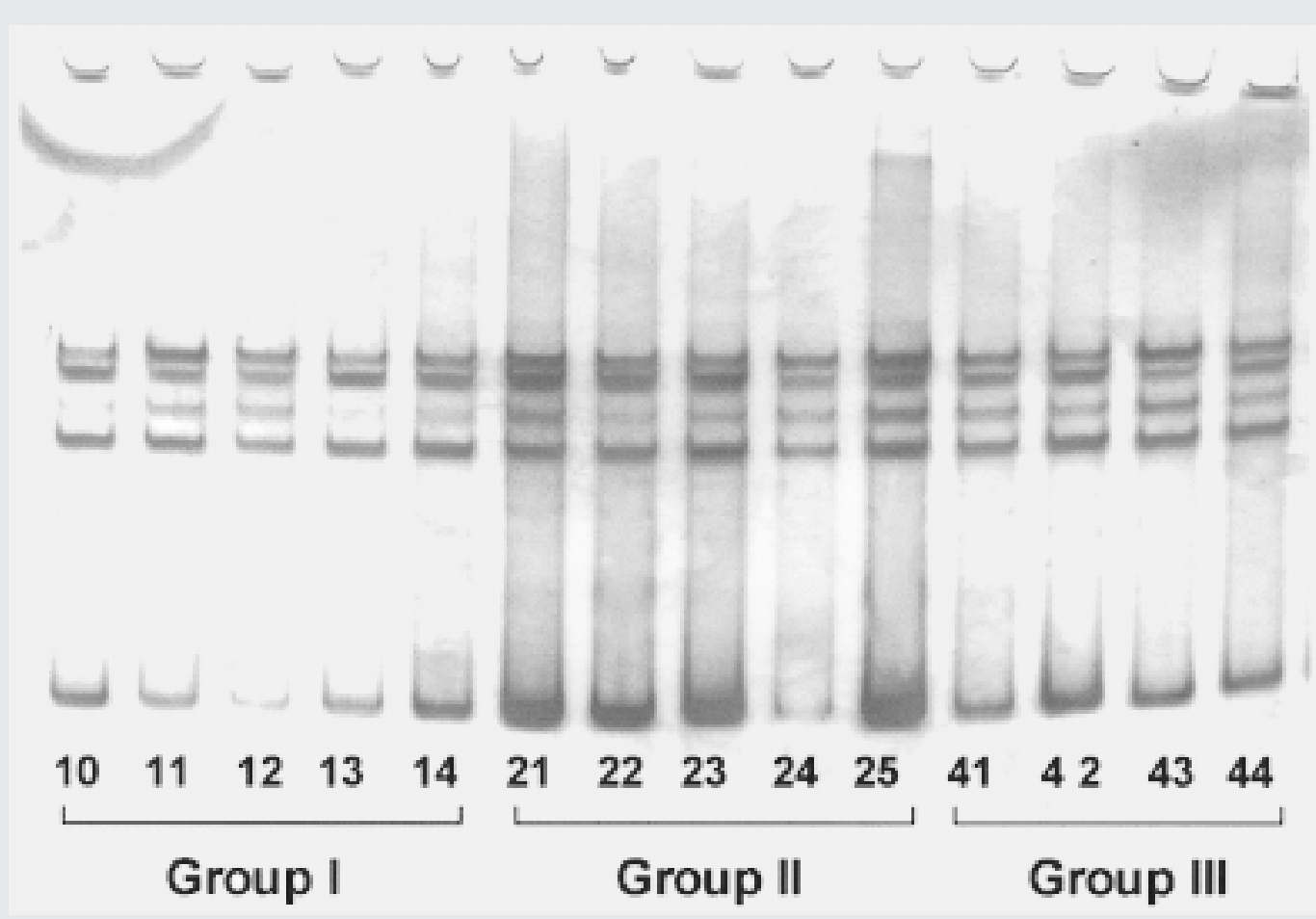

Figure 2 - PCR-SSCP showing no relevant alteration in a 7\% polyacrylamide gel for exon 6 of tumor supressor gene TP53 in group I (control, $\mathrm{n}=5)$, group II (initiated, $\mathrm{n}=5)$ and group III (initiated $+p b, \mathrm{n}=4$ )
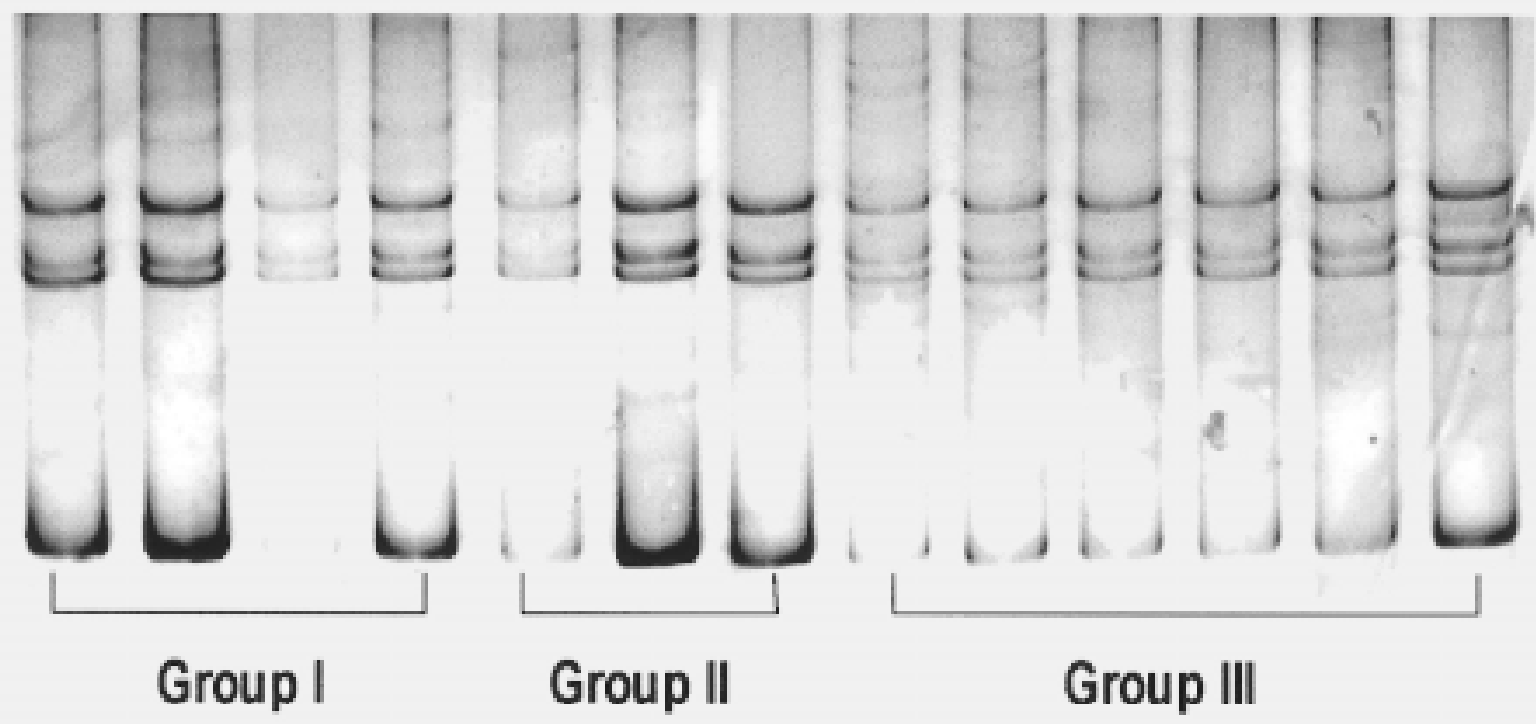

Group III

Figure 3 - PCR-SSCP showing no relevant alteration in a 14\% polyacrylamide gel for exon 2 of oncogene H-RAS in group I (control, $n=4)$, group II (initiated, $n=3$ ) and group III (initiated $+P B, n=6$ )

The PCR-SSCP technique is considered a simple and efficient methodology for screening altered DNA sequences (18). It is based on the evaluation of different electrophoretic migration patterns of the single-strands DNA obtained by denaturation of PCR products into an polyacrylamide gel (11). Although it was first described using radioactive primers ("hot-SSCP"), we used an alternative non-isotopic protocol, considered more sensitive than the original one (19). Although there are many reports using this technique $(5,26)$, it is important to point out that PCR-SSCP has limitations, independently on the protocol adopted, and should be preferentially used 
to detect point mutations that can be further studied by DNA sequencing methods $(9,12)$.

In the present study no altered banding patterns were detected by PCR-SSCP in each of the evaluated exons of TP53, K-RAS and H-RAS genes in the different experimental groups studied. These results are in accordance with other studies in the literature $(14,17,23,25,27)$, as discussed below.

Some authors suggest that the rat liver is resistant to TP53 mutations caused by chemical agents. It has been reported total absence of TP53 mutations in rats exposed to aflatoxin B1 (AFB1), a finding with no correspondence in humans, once about $50 \%$ of human tumors associated to AFB1 exposure present mutations in the TP53 gene (6, 14, 25).

By the other side, Ruggeri et al. (1991), using a radiation model of mouse skin cancer, observed significant alterations in the TP53 gene in the latter stages but not in the early stages of papiloma development (23). Similar results were found by Kress et al. (1992) in tumors induced by UV radiation: no alterations were found in papilomas, but significant mutations were detected in carcinomas (17). Taken together, these data suggest that alterations in TP53 gene are not necessarily limited to the initiation or promotion stages of carcinogenesis and probably occur late in the carcinogenic process (27).

Alterations in the RAS family genes are commonly found in chemically induced experimental tumors $(1,4)$. However, although Richmond et al. (1996) demonstrated increased expression of $\mathrm{p} 21^{\mathrm{RAS}}$ in hepatocytes from rats treated with DEN and Phenobarbital (when compared to hepatocytes of non-treated animals or only initiated ones), mutations of the coding genes were not frequently detected (22). This seems analogous to what has been observed for the TP53 gene, i.e., mutation in the gene cannot be always indirectly demonstrated by the increased expression of its product. The absence of mutations in the $\mathrm{H}$-RAS and K-RAS as registered in the present study fits data in the literature that suggest that the occurrence of mutations in these genes is influenced by the chemical carcinogen used in the experiment (2).

The efficiency of the chemical carcinogenesis protocol used (DMBDD) was demonstrated by the increased frequency of preneoplastic lesions and benign neoplasia in the initiated (Group II) and initiated/promoted groups (Group III), when compared to the non-treated group (Group I). Due to the small number of malignant neoplasia found in this study, nothing can be assured about mutation frequency in advanced lesions. Therefore, our results suggest that liver mutations in exons 5, 6, 7 and 8 of TP53 gene and exons 1 and 2 of H-RAS and K-RAS genes are not among the early molecular alterations occurring in the hepatic carcinogenesis process induced by the DMBDD protocol in male Wistar rats. The eventual role of the studied genes should be further investigated in the late progression stage of lesions induced by the DMBDD protocol. Although PCR-SSCP is a sensible technique and can be properly used to screen small mutations in an heterogeneous cell pool, DNA sequencing may confirm the present results.

\section{Acknowledgements}

We thank doctor Silvia Regina Rogatto and doctor Claudia A. Rainho for technical support and Luciana C. S. Veiga for helpful suggestions. This work was supported by FAPESP, Brazil, Grant 00/01525-0.

\section{References}

I. Belinsky, S.A. \& Anderson, M. Activation of the RAS protooncogene in rodent model systems: implications for understanding mechanisms of carcinogenicity. In: Probst, G.S. et al. (eds.). New horizons in molecular toxicology: a symposium sponsored by Toxicology Division of Lilly Research Laboratories, p. 9-|4, 199|.

2. Bitsch, A. et al. The structure and function of the H-RAS protooncogene are not altered in rat liver tumors initiated by 2acetylaminofluorene, 2-acetylaminophenanthrene and trans4-acetylaminostilbene. Toxicol. Lett., 67( I-3): I73-86, 1993.

3. Bokoch, G.M. \& Der, C.J. Emerging concepts in the RAS superfamily of GTP-binding proteins. Faseb J., 7(9): 750-9, 1993.
4. Bos, J.L. RAS oncogenes in human cancer: a review. Cancer Res., 49: 4682-9, 1989.

5. Bosari, S. et al. Detection of p53 mutations by single-strand conformation polymorphisms (SSCP) gel electroforesis: a comparative study of radioactive and non radioactive silver-stained SSCP analysis. Diagn. Mol. Pathol., 4: 249-55, 1995.

6. Bressac, B. et al. Selective G to T mutations of p53 gene in hepatocellular carcinoma from Southern Africa. Nature, 350(6317): 429-31, 1991.

7. Brown, M.A.Tumor supressor genes and human cancer. Advances in Genetics, 36: 45-135, 1997. 
8. De Camargo, J.L. et al.The detection of chemical carcinogens in an alternative medium-term bioassay. Ciência e Cultura, 5I ( I): 22-5, 1999.

9. Fan, E. et al. Limitations in the use of SSCP analysis. Mutat. Res., 288(I): 85-92, 1993.

10. Fang, X.E. et al. Chromosomal mapping of rat cellular oncogenes and growth factor genes. Cytogen. Cell. Gen., 40: 627, 1985.

I I. Fugita, K. \& Silver, J. Single-strand conformation polymorphism. In: PCR Primer: A laboratory manual. USA: Cold Spring Harbor Laboratory Press, I: 249-55, 1995.

12. Hayashi, K. \& Yandell, W. How sensitive is PCR-SSCP? Hum. Mutat., 2: 338-46, 1993.

13. Higginson, J. Environmental carcinogenesis. Cancer, 72: 97।-7, 1993.

I4. Hsu, I.C. et al. Mutation hotspot in the p53 gene in human hepatocellular carcinomas. Nature, 350(6317):427-8, 1991.

15. Ito, N. et al. Medium-term bioassays for carcinogenicity of chenical mixtures. Environ Health Perspect, 106(suppl. 6): |33|-36, 1998.

16. Kido, A. et al. p53 mutation and absence of mdm2 amplification and K-RAS mutation in 4-hydroxyamino quinoline I-oxide induced transplantable osteosarcomas in rats. Cancer Lett., I 12: 5-10, 1997.

17. Kress, S. et al. p53 mutations are absent from carcinogeninduced mouse liver tumors but occur in cell lines established from these tumors. Mol. Carcinog., 6(2): I4858,1992

182

18. Orita, M. et al. Rapid and sensitive detection of point mutations and DNA polymorphisms using the polymerase chain reaction. Genomics, 5: 874-9, 1989.

19. Oto, M. et al. Optimization of nonradioisotopic single strand conformation polymorphism analysis with a convetional minislb gel electrophoresis apparatus. Anal. Biochem., 2 I 3 : 19-22, 1993.

20. Pitot, H.C. A molecular biology of carcinogenesis. Cancer Res., 72: 962-70, 1993.

21. Raycroft, L. et al. Transcriptional activation by wild-type but not transforming mutants of the p53 anti-oncogene. Science, 249: |049-5।, 1990.
22. Richmond, R.E. Hepatocyte expression of tumor associated aldehyde dehydrogenase (ALDH-3) and p2I RAS following diethynitrosamine (DEN) initiation and chronic exposure to di(2-ethylhexyl)phthalate (DHEP). Carcinogenesis, 1 7(8): 1647-55, 1996

23. Ruggeri, B. et al.Alterations of the p53 tumor suppressor gene during mouse skin tumor progression. Cancer Res., 5 I (24): 6615-21, 1991.

24. Shimamura, A. \& Fisher, D.E. P53 in life and death. Clin. Cancer Res., 2: 435-40, 1996.

25. Smith, M.L. et al. Expression of p53 mutant protein(s) in diethylnitrosamine-induced foci of enzyme-altered hepatocytes in male Fischer-344 rats. Carcinogenesis, 12 (6): ||37-4|, |99|.

26. Soong, R. \& lacopetta, B.J.A rapid and nonisotopic method for the screening and sequencing of p53 gene mutations in formalin-fixed paraffin-embedded tumors. Mod. Pathol., 10: 252-8, 1997.

27. Stanley, L.A. Molecular aspects of chemical carcinogenesis: the roles of oncogenes and tumour suppressor genes. Toxicology, 96: 173-94, 1995.

28.Velculescu,V.E. \& El-Deiry,W.S. Biological and clinical importance of the p53 tumor suppresor gene. Clin. Chem., 42: 858-68, 1996.

29.Vogelstein, B. \& Kinzler, K.W. P53 function and dysfunction. Cell, 70: 523-6, 1992.

30. Waldmann, V. \& Rabes, H.M. What's new in as genes? Physiological role of RAS genes in signal transduction and significance of RAS gene activation in tumorigenesis. Path. Res. Pratc., 192: 883-91, 1996.

31. Wang, D. et al. Mutation in the p53 tumor suppressor gene in rat esophageal papillomas induced by $\mathrm{N}$-nitrosomethylbenzylamine. Carcinogenesis, 17:625-30, 1996.

32. Weinberg, R.A. How cancer arises. Sci. American., 62-70, September 1996.

33. Wu, J.K. et al. Sensitivity of single-strand conformation polymorphism (SSCP) analysis in detecting p53 point mutations in tumors with mixed cell populations. Am. J. Hum. Genet., 52: 1273-5, 1993. 